\title{
Determination of temporal value of a-value and b-value to identify the level brittle of rock and seismic activity in the Palu region
}

\author{
Afryanti Veronika Simangunsong ${ }^{1^{*}}$, Ramadhan Priadi ${ }^{2}$, Anak Agung Istri \\ Dwilyantari $^{3}$, Agus Marsono ${ }^{4}$ \\ 1,2,3 Meteorology Climatology and Geophysics Collage \\ ${ }^{4}$ Meteorology Climatology and Geophysics Agency \\ ${ }^{1 * a f r y a n t i v e r o n i c a @ g m a i l . c o m ~}$
}

Received 13 November 2018, Revised 21 January 2019, Published 29 March 2019

\begin{abstract}
The Palu area is a region that has a high seismic potential as a result of the existence of the Palu Koro Fault. The Koro Palu Fault is an active sinistral fault that moves with velocity around $25-30 \mathrm{~mm} /$ year. This research purpose to determine the a-value and b-value temporally for identify rock brittle levels and seismicity levels in the Palu area using the Maximum Likelihood Guttenberg-Richter method. The data used in this study are earthquake data from the BMKG and USGS catalogs for 20082018 over a period of 10 years located at $0840 \mathrm{LU} 40$ 2.620LS and 118,590 BT $-121.70 \mathrm{BT}$. Based on the results of data processing, there were 3033 earthquake distributions in the earthquake over a 10-year period. The calculation results show variations in the value of $b$-values in the range 0.55 0.961 and the a-value in the range 3.63-5.42. The highest b-value was obtained in 2015 at 0.961 as an indication of increased seismic activity in the Palu area. After the Palu M 7.4 earthquake on 28 September 2018, there was a significant decrease in the value of the b-value to 0.685 . Based on the trend of b-value values which continued to decline from 2015 until 2018, it was identified in the rock's resistance to stress is high in the Palu area. Whereas for the seismicity index value of the Palu area of 0.040789 with the earthquake return period 7 is 25 years.
\end{abstract}

Keywords: Gutenberg-Richter, Maximum likelihood, b-value, seismisity

\section{Introduction}

The outermost layer of the earth is made of a thin and hard plate. Therefore, these tectonic plates are free to move and interact with each other. The border areas of tectonic plates are places that have active tectonic conditions, which cause earthquakes, subduction pathways, volcanoes and plateau formation (Ibrahim, et al., 2010). Indonesia is a country surrounded by these plates, because of the activity of the plate movement, Indonesia is in the area of the Fire Ring Zone or commonly called Ring of Fire. 
Sulawesi Island has complex geological and tectonic conditions. Complexity is caused by the interaction of the three major plates of the world that are actively moving or also called the triple junction, namely the Australian Continent Plate that moves north, the movement of the Pacific Ocean Plate that moves west, and the relatively moving movement of the Eurasian Continent Plate to the South East (Sidarto and Bachri, 2013).

The Palu region is a region that has a high seismic potential as a result the existence of the Palu Koro Fault. This study purpose at a temporal a-value and b-value and earthquake return period as an indication of the level seismicity and the degree of brittle in the Palu region. The method used in determining the parameters of earthquake activity is the Maximum Likelihood method developed by Gutenberg-Richter. The vulnerability of rocks in a region is determined by the magnitude of the b-value in an area. The b-value obtained from the equation of the earthquake magnitude and frequency formulated by Gutenberg-Richter as follows:

$$
\begin{aligned}
& b=\frac{\log e}{\bar{M}-M_{0}} \\
& a=\log N+\log B \ln 10+M_{0} b
\end{aligned}
$$

Where,

$$
\begin{aligned}
& \bar{M}=\text { Average magnitude } \\
& M_{0}=\text { Minimum magnitude } \\
& \mathrm{N}=\text { amount of data } \\
& \log e=0.4343
\end{aligned}
$$

Magnitude completeness (Mc) is an important parameter in determining a-value and b-value, where Mc represents the completeness of the data so that it can find out its complete magnitude (Elhuda et al., 2016.). The maximum likelihood method is used to determine the relationship between earthquake frequency and magnitude. This is also explained by Pasau and Tanauma (2011) that earthquake parameter estimation using statistical analysis of the maximum likelihood model, gives more stable results because it models the slope of the line not from the fitting least square of magnitude, but the slope of the mean distribution function Gaussian.

Research on spatial $b$-value variations has been carried out by experts in a number of earthquake-active areas. The experts concluded that the b-values did not vary systematically (constant) and estimated their values ranged from 1.0, (Schorlemmer and Winner, 2004) and several other experts showed that b-values varied significantly in several fault zones (Wesnousky, 1983) and (Schorlemmer and Winner, 2004) also in some places and certain time periods (Nuaninin et al., 2005), b-value also varies laterally to depth (Kulhanek, 2005).

$\mathrm{B}$-value can indicate the brittle level of rocks. The greater b-value means the greater the brittle level of the rock and the smaller the resistance to stress. And the greater the avalue means the greater the level of seismicity in the area (Nuannin, 2005), (Mudamakin, 2012), and (Happrobo, 2014). 


\section{Method}

The data used is earthquake data from the USGS and BMKG catalogs from January 2008 to October 2018 over a period of 10 years with a focus on the Palu area with the limitation of the study area being 0.840 LU - 2.620 LS and 118.590 BT - 121,700 BT. During this period there were 3033 earthquakes in the Palu area.

Data from earthquake parameters used in determining a-value and b-values are the origin time, magnitude, and epicenter of an earthquake. These parameters are then used as inputs in zmap tools. The a-value and b-value that have been obtained are used to obtain the seismicity index with the following equation:

$N 1\left(M \geq M_{0}\right)=10^{\left.(a-\log (b \ln 10)-\log \Delta \mathrm{t})-\mathrm{b} M_{0}\right)}$

The symmetry index can be used to determine the total earthquake event with a force greater than M0 that occurs in one year, M0 used in this study is M7.0. Based on the calculation results of the seismicity index, it can be seen the average return period of earthquakes with M 7.0 through the formula:

$\theta\left(M \geq M_{0}\right)=\frac{1}{N 1\left(M \geq M_{0}\right)}$

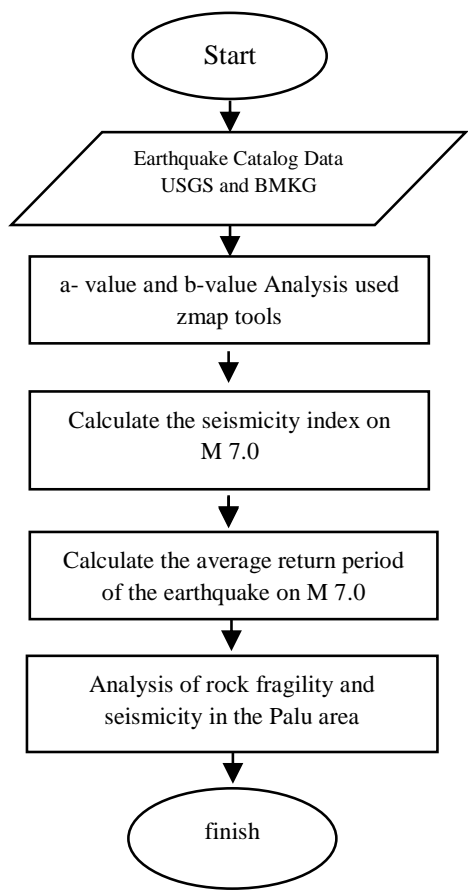

Figure 1. Research Flow Chart

\section{Result}

The Palu area is a region with a high level of seismicity, it is also increasingly strengthened after the hammer M 7.5 occurred. After Palu earthquake M 7.5 is recorded if there have been as many as 634 aftershocks recorded by seismic sensors. Aftershock is a series of major earthquakes that indicate the release of residual energy after the rock breaks in stages to reach equilibrium again. The results of processing for the Palu region are obtained if the $b$-value for the Palu region is 0.585 with identification if the $b$-value 
value is a seismotectonic parameter from an area that usually approaches 1 and shows the relative number of small vibrations and large vibrations. The temporal $b$-value value for the hammer region in the 2008-2018 period was in the range of 0.55-0,961 with the highest b-value obtained in 2015 amounting to 0.961 as an indication of increased seismic activity in the Palu area. The higher the value of $b$-value, the higher the brittle level of rocks in an area, but the resistance to stress is very low.

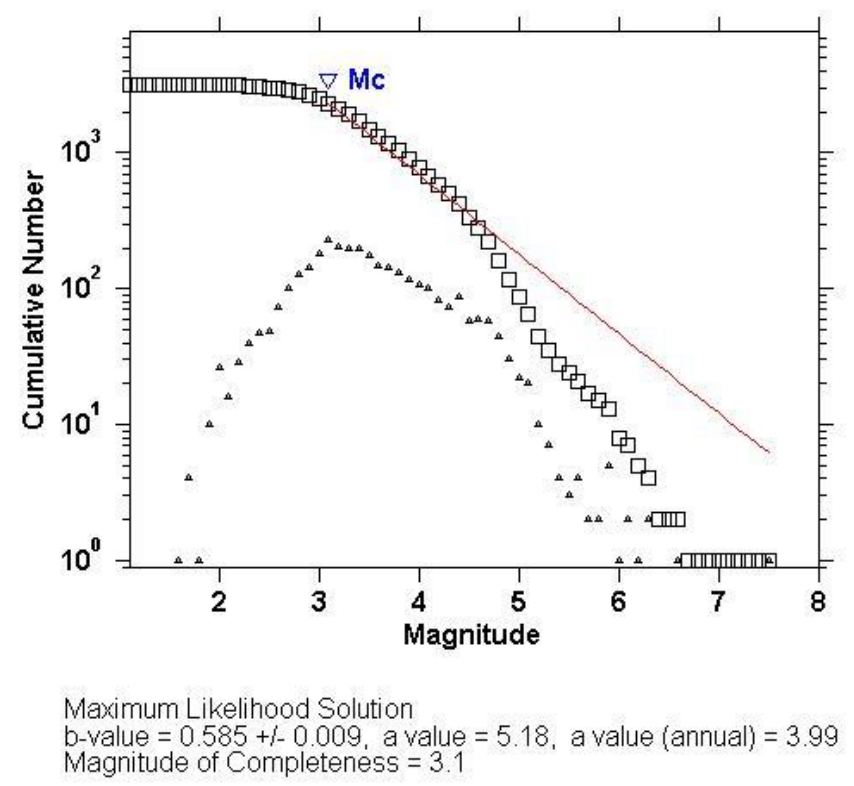

Figure 2. Frequency distribution of the magnitude of the Palu area

Figure 2 shows the frequency distribution of magnitude for the Palu region. The frequency of magnitude that often occurs is in the magnitude range M 3.0 - M 4.0 with a magnitude of the magnitude of 3.1 which indicates the level of quality of the data obtained. In the Palu region, an a-value of 5.18 with an a-annual value of 3.99 is obtained. Temporal a-value in the Palu region in the period 2008-2018 in the range 3.63 - 5.42 where the a-value is a seismic parameter whose magnitude depends on the number of earthquake events. So that the greater the value of a-value, the higher the level of seismic activity in a region. 


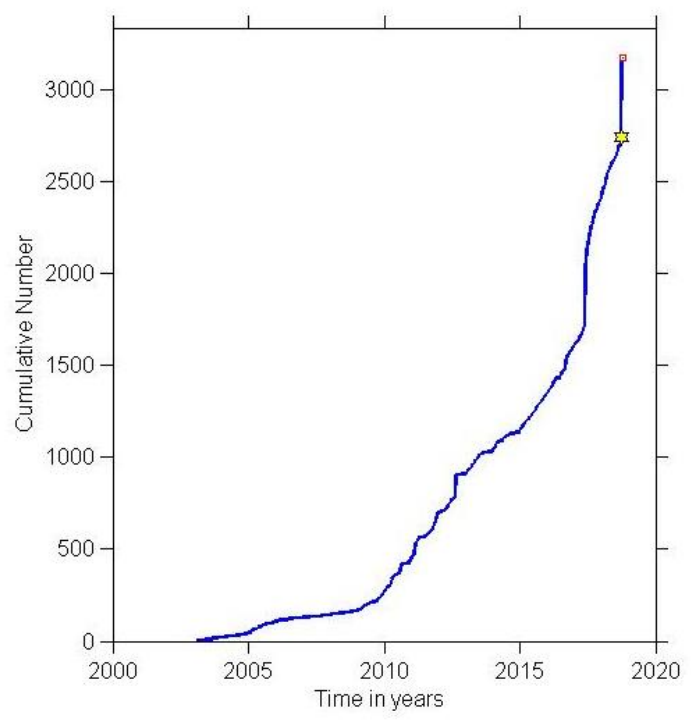

Figure 3. Time window of earthquake distribution in the Palu area

From the time-window shown in figure 3, according to (Mogi, 1963) the Palu earthquake was classified into a type 2 earthquake which was a series of earthquakes which was preceded by a foreshock before the main earthquake followed by many aftershocks. From this series of earthquakes identify if the deformation of the earthforming material where the earthquake occurred is semi-homogeneous.

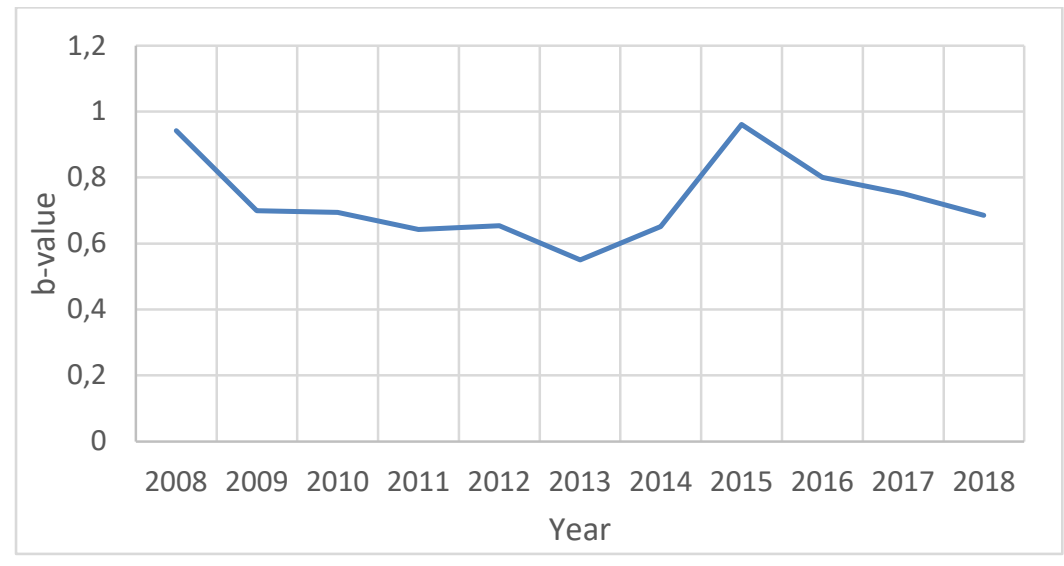

Figure 4. Graph of temporal b-value in the Palu area

In figure 4 it is shown if the b-value changes over time with seismic activity. The highest b-value was calculated in 2015 with a b-value of 0.96 . In 2015 it was identified if rocks in the hammer region experienced a period where the fragility of rocks was very high with low-stress resistance. This is because fragile rocks describe if rocks are brittle or easily broken.

From 2015-2018 the value of b-value in the hammer region has gradually decreased as seen in Figure 4 which shows a trend that continues to decline from 2015-2018. It is assumed that during this period the rocks surrounding the hammer region received stress from the movement of the koro Palu fault and the surrounding segments so that the rock resistance to stress increased from 2015 to 2018. 


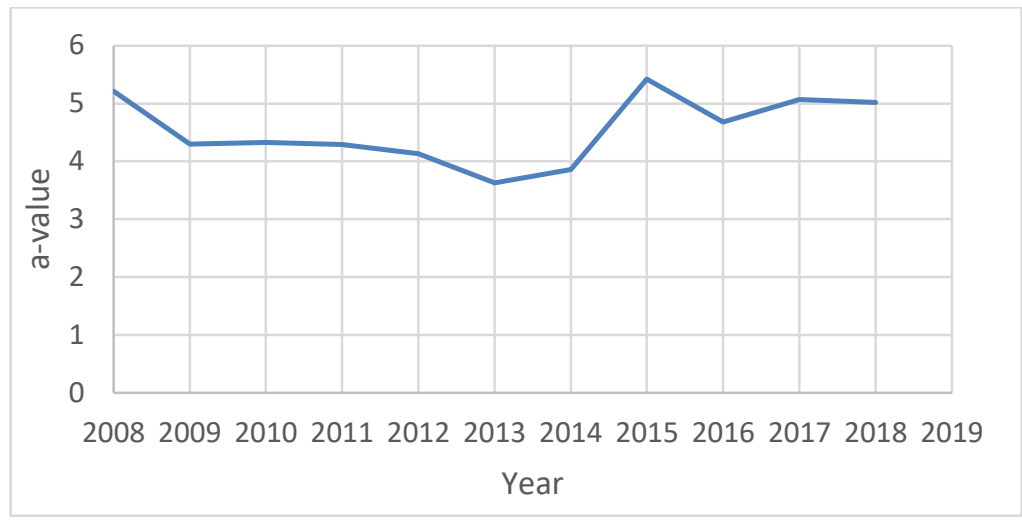

Figure 5. Graph of temporal a-value in the Palu area

The same thing also happened in the temporal a-value in the Palu region as shown in Figure 5. In figure 5, it can be seen if the biggest a-value is in 2015 with an a-value of 5.42, this indicates that the highest seismic activity in the Palu area occurs in 2015 but experienced a decline in 2016 and then experienced an increase in activity again in 2017. When low b-value represents if the region has a high resistance to stress that allows the occurrence of periodic energy accumulation before finally broken rocks due to stress is given has exceeded rock elasticity limit. From these data, it is known that before the Palu M 7.5 earthquake there was an accumulation of stress in the 2015-2018 period and finally, it broke out in 2015 because the rocks elasticity limit had been exceeded.

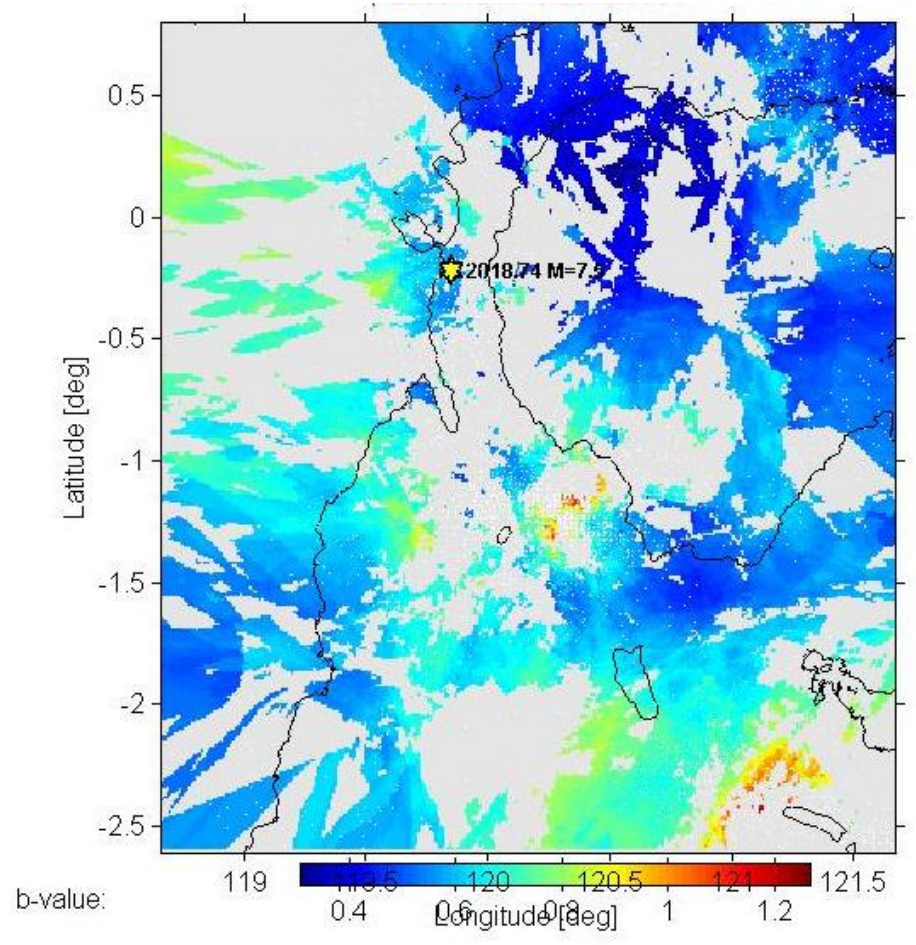

Figure 6. Distribution of b-value values in Palu region for the period 2008-2018 
Figure 6 shows the distribution of the value of the Palu b-value in the period 20082018. Areas with very high rock fragility are in the Palu Koro fault area with a b-value between $0.8-1$. In the case of earthquakes, the M 7.5 epicenter area has a b-value value of 0.6 to 0.8 which indicates that the rock layers of the donggala region have a high resistance to stress which allows for a large accumulation of energy.

Table 1. Table of changes in b-value and a-value temporarily in 2008-2018 period

\begin{tabular}{ccccc}
\hline Year & $b$-value & $a$-value & a-value annual & $\mathrm{MC}$ \\
\hline 2008 & 0.942 & 5.21 & 5.24 & 4.2 \\
2009 & 0.699 & 4.3 & 4.31 & 3.7 \\
2010 & 0.694 & 4.33 & 4.34 & 3.3 \\
2011 & 0.642 & 4.29 & 4.3 & 3.1 \\
2012 & 0.654 & 4.13 & 4.14 & 3 \\
2013 & 0.55 & 3.63 & 3.64 & 3.1 \\
2014 & 0.651 & 3.86 & 3.87 & 3.2 \\
2015 & 0.961 & 5.42 & 5.42 & 3.8 \\
2016 & 0.801 & 4.68 & 4.69 & 3.1 \\
2017 & 0.751 & 5.07 & 5.08 & 3.1 \\
2018 & 0.685 & 5.02 & 5.14 & 3.5 \\
\hline
\end{tabular}

Table 1 shows changes in b-value and a-value temporally in the period 2008-2018. From table 1, it can be seen if the biggest b-value and a-value are in 2015 . From the bvalue and a-value, it can calculate the seismic index value and the return period of an earthquake in a region. From the calculation results obtained if the seismicity index of the Palu area is 0.040789 with the return period for the earthquake M 7 is 25 years. Regions that have a large seismicity index with a low return period indicate that the area is an earthquake-prone area or has a high earthquake risk. Likewise, the opposite for high return periods with a small seismicity index indicates that the area is a region with low earthquake risk.

\section{Reference}

Agustiawati, A., Mei, I. B. H., \& Si, M. (n.d.). Studi B-Value Untuk Analisis Seismisitas Berdasarkan Data Gempabumi Periode 1904-2014.

Budiman,Arif., dkk. 2011. Analisis Periode Ulang dan Aktivitas Kegempaan Pada Daerah Sumatera Barat dan Sekitarnya.Jurnal Ilmu Fisika, 3(2).

Elhuda, I., Agustawijaya, D. S., \& Sulistiyono, H. (n.d.). Evaluation of Earthquake Territory in Lombok using Statistical Method.

Gutenberg, B., \& Richter, C. F. (1944). Frequency of earthquakes in California. Bulletin of the Seismological Society of America, 34(4), 185-188.

Happrobo, Satrio. Variasi B-Value Terhadap Ruang Dan Waktu Sebagai Precursor Gempa Bumi Daerah Andaman-Sumatera. Banda Aceh : Fakultas MIPA 
Universitas Syiah Kuala, 2014.

Ibrahim, G., Subardjo, \& Senjaya, P. (2010). Tektonik dan Mineral di Indonesia. Jakarta, Puslitbang BMKG.

Kulhanek, Ota., 2005, Seminar on b-Value, Prague: Dept of Geophysics, Charles University.

Kurz, J. H., Finck, F., Grosse, C. U., \& Reinhardt, H.-W. (2006). Stress drop and stress redistribution in concrete quantified over time by the b-value analysis. Structural Health Monitoring, 5(1), 69-81.

Mogi, K. (1963). Some discussions on aftershocks, foreshocks and earthquake swarms: the fracture of a semi-infinite body caused by an inner stress origin and its relation to the earthquake phenomena (third paper).

Mudamakin, Philips Bramantia.2012. Perhitungan Nilai-B Sebelum Dan Sesudah Gempa Padang 30 September 2009 Secara Spatial Dan Temporal. Sekolah Tinggi Meteorologi Klimatologi dan Geofisika: Tangerang Selatan.

Nuannin, Paiboon., Kulhanek, Ota., Persson, Leif., 2005, Spatial and Temporal bValue Anomalies Precedding the Devastating off Coast of NW Sumatra Earthquake of December 26, 2004, Geophysical Research Latter 32, L11307.

Schorlemmer, D., Winner, S., 2004, Earthquake Statistic at Parkfield: Stationary of bValues, Journal of Geophysical Research, Vol. 109.

Pasau, G., dan A. Tanauma. 2011. Pemodelan Sumber Gempa di Wilayah Sulawesi Utara Sebagai Upaya Mitigasi Bencana Gempa Bumi. Journal science of MIPA. 7:1-5.

Pusat Studi Gempa Nasional. 2017. Peta Sumber Dan Bahaya Gempa Indonesia Tahun 2017. Jakarta: Pusat Litbang Perumahan dan Permukiman.

Sidarto., Bachri, Syaiful. 2013. Tektonik Sulawesi. Jakarta: LIPI Press. 